\title{
Alterations in Renal Cortex Cation Homeostasis during Mercuric Chloride and Gentamicin Nephrotoxicity
}

\author{
Joel M. Weinberg,' Phillip G. Harding, and H. David Humes \\ Departments of Internal Medicine, Veterans Administration Medical Center, Ann Arbor, Michigan \\ 48105, and University of Michigan, Ann Arbor, Michigan 48109
}

Received October 6, 1982, and in revised form December 10, 1982

\begin{abstract}
To help better understand the role of changes in cellular cation homeostasis in the pathogenesis of renal tubular cell injury, the alterations in cation content of renal cortex and isolated renal cortical mitochondria occurring during models of nephrotoxicity secondary to gentamicin and $\mathrm{HgCl}_{2}$ were determined both during a developing phase of injury prior to the appearance of cell necrosis and after advanced injury when cell necrosis was present. At $3 \mathrm{hr}$ after $5 \mathrm{mg} / \mathrm{kg} \mathrm{HgCl}$ or after 4 daily doses of $100 \mathrm{mg} / \mathrm{kg}$ gentamicin, tubular cell integrity was still intact but mitochondrial functional changes were present. There were no alterations of renal cortex tissue electrolytes at this stage in the $\mathrm{HgCl}_{2}$ model but tissue $\mathrm{K}^{+}$, and more prominently, tissue $\mathrm{Mg}^{2+}$ were decreased in the gentamicin model. $\mathrm{K}^{+}$and $\mathrm{Mg}^{2+}$ contents of isolated mitochondria were slightly reduced after $\mathrm{HgCl}_{2}$. Only $\mathrm{K}^{+}$content was slightly reduced after gentamicin. No evidence for tissue or mitochondrial $\mathrm{Ca}^{2+}$ overload was present in either model. At $12 \mathrm{hr}$ after $5 \mathrm{mg} / \mathrm{kg} \mathrm{HgCl}$ or after 10 daily $100 \mathrm{mg} /$ $\mathrm{kg}$ doses of gentamicin, widespread areas of tubular cell necrosis were present and the function of isolated mitochondria was severely compromised. Tissue electrolytes at this stage of injury in both models were characterized predominantly by a twofold increase in $\mathrm{Na}^{+}$content and five- to sixfold increases in $\mathrm{Ca}^{2+}$. Isolated mitochondria showed marked decreases in $\mathrm{K}^{+}$content and marked increases in content of $\mathrm{Na}^{+}$and $\mathrm{Ca}^{2+}$. These data suggest that neither cellular and mitochondrial $\mathrm{Ca}^{2+}$ overload nor substantial changes in cellular $\mathrm{Na}^{+}$and $\mathrm{K}^{+}$homeostasis can be implicated in the early stages of renal tubular cell injury produced by gentamicin and $\mathrm{HgCl}_{2}$.
\end{abstract}

\section{INTRODUCTION}

Alterations in the integrity of cellular and subcellular membranes have been proposed to play critical roles in the pathogenesis of cellular injury in various tissues, including the kidney (Trump et al., 1976; Jennings and Reimer, 1981; Farber et al., 1981; Farber, 1982; Humes and Weinberg, 1983). The resulting loss of the major intracellular cations, $\mathrm{K}^{+}$and $\mathrm{Mg}^{2+}$, and intracellular overload with the major extracellular cations, $\mathrm{Na}^{+}$and, particularly, $\mathrm{Ca}^{2+}$, have the potential to contribute to the disruption of multiple intracellular processes and, thereby, to the pathogenesis of irreversible cell injury. When studied in vitro, many nephrotoxins alter the permeability properties of both the plasma membrane as well as subcellular organellar membranes (Humes and Weinberg, 1982; Humes and Weinberg, 1983a). However, little is known about the extent to which such interactions may contribute to pertubations in cellular cation homeostasis during in vivo toxicity. This complex process is dependent, not only on the nature of the direct interaction between membrane and toxin, but also on the availability of the toxin in vivo to interact at various sites and the intactness of compensatory mechanisms. The present study was designed to assess the importance of altered cellular cation homeostasis in the pathogenesis of two well-studied models of nephrotoxic

\footnotetext{
1 To whom reprint requests should be addressed: Research Service (151), VA Medical Center, Ann Arbor, Mich. 48105.
} 
renal tubular cell injury, acute renal failure (ARF) secondary to gentamicin and $\mathrm{HgCl}_{2}$. For each model, effects during the early developing phase of injury were contrasted with those present during advanced injury. Since mitochondrial function is altered during the early developing phases of renal tubular injury secondary to gentamicin (Simmons et al., 1980) and $\mathrm{HgCl}_{2}$ (Weinberg et al., 1982a; Weinberg et $a l .1982 \mathrm{~b}$ ) and since marked alterations in mitochondrial cation homeostasis occur after in vitro exposure to these nephrotoxins (Weinberg et al., 1982a; Weinberg and Humes, 1980; Weinberg et al., 1980) cation levels of isolated renal cortical mitochondrial were measured in addition to whole renal cortex cation content.

\section{METHODS}

\section{Animals}

Male Sprague-Dawley rats weighing 275-325 g and allowed free access to food and water were used for all studies.

\section{Nephrotoxin Treatment Procedures}

(a) $\mathrm{HgCl}_{2}$ was administered as a single subcutaneous injection of $5 \mathrm{mg} \mathrm{HgCl}_{2} /$ $\mathrm{kg}$ body $\mathrm{wt}$ in a volume of approximately $0.4 \mathrm{ml}$ of an aqueous solution. Studies were done at 3 and $12 \mathrm{hr}$ after $\mathrm{HgCl}_{2}$.

(b) Gentamicin was administered as a single daily subcutaneous injection of $100 \mathrm{mg}$ gentamicin $/ \mathrm{kg}$ body wt in a volume of approximately $0.7 \mathrm{ml}$ of an aqueous solution of gentamicin sulfate. Studies were done at $24 \mathrm{hr}$ after the last of 1, 2, 4 , and 10 daily doses of gentamicin.

Control groups were always run simultaneously with each experimental group and, for the purpose of statistical analysis, data from experimental groups are compared only to data from the corresponding control groups.

\section{Procedures for Obtaining Tissue and Mitochondrial Samples}

Rats were stunned, decapitated, and both kidneys removed and placed in icecold $0.275 M$ sucrose for 1-2 min. The kidneys were then gently blotted dry, and their capsules removed. The renal cortices were dissected, and, as required for specific experiments, tissue samples were taken for determination of wet and dry weights and isolation of renal cortical mitochondria. In studies where samples of muscle were required they were obtained from the left thigh and were carefully stripped of connective tissue.

To isolate renal cortical mitochondria, the dissected cortex was minced on an ice-cold tile plate, then placed in $14 \mathrm{ml}$ of an ice-cold solution of $0.275 \mathrm{M}$ sucrose, $1 \mathrm{~m} M$ EGTA, ${ }^{2} 5 \mathrm{~m} M$ Tris-HCl, pH 7.4, in a Potter Elvehjem homogenizer (Thomas size $\mathrm{BB}$ ) and homogenized with a motor-driven Teflon pestle. A sample of this homogenate was saved for determination of protein and electrolyte content in a dry plastic tube previously rinsed with dilute $\mathrm{HCl}$ and mitochondria were isolated from the remainder by differential centrifugation as previously detailed (Weinberg et al., 1982a). The final mitochondrial resuspension was in $0.275 M$ sucrose and was stored in a dry plastic tube previously rinsed with dilute $\mathrm{HCl}$.

\footnotetext{
${ }^{2}$ Abbreviations used: EGTA, ethylene glycol bis( $\beta$-aminoethyl ether) $N, N^{\prime}$-tetraacetate; Tris, tris(hydroxymethyl)aminomethane.
} 


\section{Measurements of Electrolyte Levels}

Dried tissue samples. Samples of renal cortex were weighed to obtain the wet tissue weight in tared glass tubes, then dried for $24 \mathrm{hr}$ at $180^{\circ} \mathrm{C}$ and reweighed to obtain the dry weight. Tissues were then digested and dissolved in concentrated $\mathrm{HNO}_{3}$ (approximately $1 \mathrm{ml} \mathrm{HNO} / 200 \mathrm{mg}$ dry tissue) (Humes and Weinberg, 1983a).

$\mathrm{Na}^{+}$and $\mathrm{K}^{+}$levels in the $\mathrm{HNO}_{3}$ tissue digests were measured on a Beckman Klina flame photometer. $\mathrm{Mg}^{2+}$ levels were measured on aliquots of the $\mathrm{HNO}_{3}$ digests diluted 1:400 with $1 \% \mathrm{La}_{2} \mathrm{O}_{3}$ on a Perkin Elmer model 306 atomic absorption spectrophotometer (AAS). $\mathrm{Ca}^{2+}$ levels were similarly measured using the AAS on 1:50 dilutions. Concentrated $\mathrm{HNO}_{3}$ incubated in glass tubes without tissue served as the blank. Electrolyte levels are reported as nanomoles per milligram dry tissue weight.

Tissue homogenates and mitochondrial suspensions. Both preparations were handled similarly. The samples were frozen and thawed at least twice before determination of electrolytes and all dilutions were done in $0.0125 \%$ Acationox (Scientific Products), a detergent with extremely low cation content (Aithal and Toback, 1978). All electrolyte measurements were done on a Perkin Elmer model 306 AAS.

$\mathrm{Na}^{+}$was determined on 1:150 and 1:7.5 dilutions of homogenates and mitochondria, respectively. $\mathrm{K}^{+}$was determined on $1: 300$ and $1: 75$ dilutions of homogenates and mitochondria, respectively. The diluting solution used in the AAS determinations of $\mathrm{Na}^{+}$and $\mathrm{K}^{+}$was prepared as described in Willard et al. (1974) and contained $247 \mathrm{mg} \mathrm{Li}_{2} \mathrm{CO}_{3}, 1.5 \mathrm{ml}$ concentrated $\mathrm{HCl}$, and deionized, glassdistilled water to a volume of $1000 \mathrm{ml}$. Acationox was added to a concentration of $0.0125 \%$.

$\mathrm{Mg}^{2+}$ was determined on 1:50 and 1:25 dilutions of homogenates and mitochondria respectively. $\mathrm{Ca}^{2+}$ was determined on 1:10 and 1:5 dilutions of homogenates and mitochondria, respectively. For $\mathrm{Mg}^{2+}$ and $\mathrm{Ca}^{2+}$ determinations all samples and standards were diluted in a solution made by adding 11.7 grams $\mathrm{La}_{2} \mathrm{O}_{3}$ and $50 \mathrm{ml}$ concentrated $\mathrm{HCl}$ to deionized, glass-distilled water to a volume of $1000 \mathrm{ml}$. Acationox was added to a concentration of $0.0125 \%$.

All dilutions were done in dry plastic tubes previously rinsed with dilute $\mathrm{HCl}$.

Solutions containing either $0.275 M$ sucrose or $0.275 M$ sucrose, $1 \mathrm{~m} M$ EGTA, $5 \mathrm{mM}$ Tris- $\mathrm{HCl}$, pH 7.4, were diluted exactly as the samples and served as blanks for mitochondria and homogenates, respectively.

Electrolyte levels obtained are reported as $\mathrm{nmol} / \mathrm{mg}$ homogenate or mitochondrial protein.

The validity of these tissue-handling procedures for measuring the total electrolyte content of the homogenate and mitochondrial samples was established by several procedures.

(1) Addition of known amounts of electrolytes to the samples before their dilution resulted in quantitative recovery.

(2) In comparing renal cortex samples dried and then digested in nitric acid with those which were homogenized, the electrolyte levels determined on the nitric acid digests were the same as those determined on the homogenates when the ratio of $\mathrm{mg}$ tissue protein $/ \mathrm{mg}$ tissue dry weight was accounted for.

(3) Mitochondrial and homogenate samples spanning a range of $\mathrm{Ca}^{2+}$ levels from 10 to $600 \mathrm{nmol} / \mathrm{mg}$ protein gave the same values when measured by the 
procedures used in the present paper as when measured using a recently reported Butanol:HCl-lanthanum extraction method (Tew et al., 1981).

Serum samples. $\mathrm{Mg}^{2+}$ was measured by AAS on 1:75 dilutions of serum in the same lanthanum solution used for mitochondrial samples. Serum $\mathrm{K}^{+}$levels were measured on a Beckman Klina flame photometer.

\section{Measurement of Mitochondrial Respiration}

Well-standardized procedures were used exactly as described previously (Weinberg et al., 1982a).

\section{Morphologic Studies}

Rats were anesthetized with intraperitoneal sodium pentobarbital and the kidneys were perfused in situ for $8 \mathrm{~min}$ via a catheter in the lower abdominal aorta with a solution containing $100 \mathrm{mM}$ sodium cacodylate $\mathrm{pH} 7.4$ and $2 \%$ gluteraldehyde at $37^{\circ} \mathrm{C}$ and a perfusion pressure of $150 \mathrm{~mm} \mathrm{Hg}$. Then the kidneys were removed and hemisected. A 3-mm-thick slice of one hemisection was placed in $4 \%$ formaldehyde, $1 \%$ gluteraldehyde, $84 \mathrm{mM}$ sodium phosphate, $\mathrm{pH} 7.2$, for at least $24 \mathrm{hr}$, then mounted in paraffin, sectioned, and stained with hematoxylin and eosin (H\&E). One-millimeter-thick slices of the other hemisections were saved in the same fixative and samples from about one-half of the rats in each group were subsequently processed by postfixation in osmium, staining with uranyl acetate, sequential dehydration in increasing concentrations of ethanol, and embedding in Epon. Semithin sections were stained with toluidine blue and examined by light microscopy and areas of these were further processed for electron microscopy as required to clarify details of fine structure.

Quantitative assessment for the presence of advanced renal tubular cell injury was done with light microscopy of the H\&E-stained hemisections. For each section we graded in a blinded fashion the amount of injury present in 20 proximal tubules in each of three areas: (1) outer cortex just beneath the capsule (early sections of proximal convoluted tubule), (2) medullary ray (late part of proximal convoluted tubule, early sections of proximal straight tubulc), and (3) outer medulla just beneath corticomedullary junction (proximal straight tubules).

The scale used for grading was

0 - Completely normal tubule with full extent of fine detail of entire brush border clearly discernible.

1-All cells completely intact but various focal brush border abnormalitiessmudging, focal loss, decrease in height, brush border debris in lumenwere present. Any such abnormality, no matter how minor, was sufficient to place a tubule in this category, accounting for its frequent occurrence in control kidneys as detailed in Table I.

2-Abnormal large vacuoles present within tubule cells. Projections of tubule cell cytoplasm into lumen. These findings were almost always accompanied by moderate to extensive loss of brush borders.

3-Loss or obvious detachment from basement membrane of no more than 12 individual tubular cells per tubule. Tubules with this finding always had extensive loss of brush borders in remaining cells and frequently but not always had grade 2 cellular vacuolization.

$4-$ Obvious necrosis of majority of cells within tubule with loss and/or detach- 
TABLE I

Morphology of Models of Injury ${ }^{a}$

\begin{tabular}{|c|c|c|c|c|c|c|}
\hline & \multicolumn{6}{|c|}{ Stage of injury } \\
\hline & 0 & 1 & 2 & 3 & 4 & 5 \\
\hline \multicolumn{7}{|c|}{ Control $(N=10)$} \\
\hline OC & $36 \pm 13$ & $64 \pm 13$ & 0 & 0 & 0 & 0 \\
\hline MR & $55 \pm 10$ & $45 \pm 10$ & 0 & 0 & 0 & 0 \\
\hline $\mathrm{OM}$ & $60 \pm 14$ & $40 \pm 14$ & $\mathbf{0}$ & 0 & 0 & 0 \\
\hline \multicolumn{7}{|c|}{$\begin{array}{l}\text { 4-Dose gentamicin } \\
\qquad(N=5)\end{array}$} \\
\hline $\mathrm{OC}$ & $30 \pm 18$ & $70 \pm 18$ & 0 & 0 & 0 & 0 \\
\hline MR & $20 \pm 11$ & $80 \pm 11$ & $\mathbf{0}$ & 0 & 0 & 0 \\
\hline $\mathrm{OM}$ & $26 \pm 15$ & $74 \pm 15$ & 0 & 0 & 0 & 0 \\
\hline \multicolumn{7}{|c|}{$\begin{array}{l}\text { 10-Dose gentamicin } \\
(N=6)\end{array}$} \\
\hline OC & 0 & $10 \pm 9$ & $3 \pm 3$ & $8 \pm 5$ & $6 \pm 5$ & $73 \pm 16$ \\
\hline MR & 0 & $12 \pm 11$ & $30 \pm 11$ & $33 \pm 7$ & $15 \pm 8$ & $10 \pm 6$ \\
\hline OM & $22 \pm 9$ & $60 \pm 6$ & $18 \pm 7$ & 0 & 0 & 0 \\
\hline \multicolumn{7}{|c|}{$\begin{array}{l}5 \mathrm{mg} / \mathrm{kg} \mathrm{HgCl}{ }_{2}, 3 \mathrm{hr} \\
\quad(N=7)\end{array}$} \\
\hline $\mathrm{OC}$ & $28 \pm 9$ & $72 \pm 9$ & 0 & $\mathbf{0}$ & 0 & 0 \\
\hline MR & $18 \pm 8$ & $82 \pm 8$ & 0 & 0 & 0 & 0 \\
\hline OM & $48 \pm 17$ & $52 \pm 17$ & 0 & 0 & 0 & 0 \\
\hline \multicolumn{7}{|c|}{$\begin{array}{c}5 \mathrm{mg} / \mathrm{kg} \mathrm{HgCl}_{2}, 12 \mathrm{hr} \\
(N=4)\end{array}$} \\
\hline $\mathrm{OC}$ & 0 & $32 \pm 15$ & $55 \pm 10$ & $13 \pm 5$ & 0 & 0 \\
\hline MR & $\mathbf{0}$ & 0 & 0 & $28 \pm 9$ & $60 \pm 5$ & $12 \pm 11$ \\
\hline OM & 0 & 0 & 0 & 0 & $78 \pm 20$ & $22 \pm 20$ \\
\hline
\end{tabular}

a Each value is the mean percent of tubules $( \pm S E$ ) falling into the indicated morphologic stage. OC-outer cortex, MR-medullary ray, $\mathrm{OM}$-outer medulla at corticomedullary junction. $N$ indicates number of animals studied.

ment of cells from basement membrane, extensive vacuolization, and loss of normal cell contour.

5-Maximum loss of normal tubular architecture with extensive bare and sometimes disrupted areas of basement membrane and/or extensive debris, no longer bearing any resemblance to normal mature tubular cells.

Results are reported as mean percent of tubules graded falling into each category.

BUN levels were determined as previously described (Weinberg et al., 1982b) on serum obtained at the time of sacrifice.

Proteins were determined by the Lowry method (Lowry et al., 1951) with bovine serum albumin (Sigma A7511) as standard.

All reagents were of the highest purity commercially available. Organic compounds, including gentamicin sulfate, were obtained from Sigma Chemical Company. All water used was deionized and glass-distilled.

Unpaired $t$ tests were used for statistical analyses with $P<0.05$ two-tailed considered to be statistically significant. 
TABLE II

BUN Levels after Gentamicin and $\mathrm{HgCl}_{2}$ Treatment ${ }^{a}$

\begin{tabular}{lccc}
\hline & \multicolumn{3}{c}{$\begin{array}{c}\text { Number of daily } \\
100 \mathrm{mg} / \mathrm{kg} \text { doses } \\
\text { of gentamicin }\end{array}$} \\
\cline { 2 - 4 } & Control & 4 & 10 \\
\hline$N$ & 11 & 14 & 5 \\
BUN (mg/d) & 16 & 18 & $121^{* * *}$ \\
& \pm 1 & \pm 1 & \pm 14 \\
& & Hours after & \\
& Control & $5 \mathrm{mg} / \mathrm{kg} \mathrm{HgCl} l_{2}$ & 12 \\
\hline$N$ & 17 & 3 & 8 \\
BUN (mg/dl) & 19 & 18 & \pm 4 \\
& \pm 1 & 22 & \pm 1 \\
\hline
\end{tabular}

${ }^{a} N=$ number of experiments. Relative to control, ${ }^{*} P<0.05$, ${ }^{* *} P<0.01,{ }^{* * *} P<0.001$.

\section{RESULTS}

\section{Renal Function and Morphologic Effects}

The alterations in BUN resulting from the treatment protocols used are summarized in Table II. Representative sections of renal cortex under each of the experimental conditions studied are illustrated in Figs. 1-4 and results of quantitative morphologic studies are summarized in Table I. Twenty-four hours after

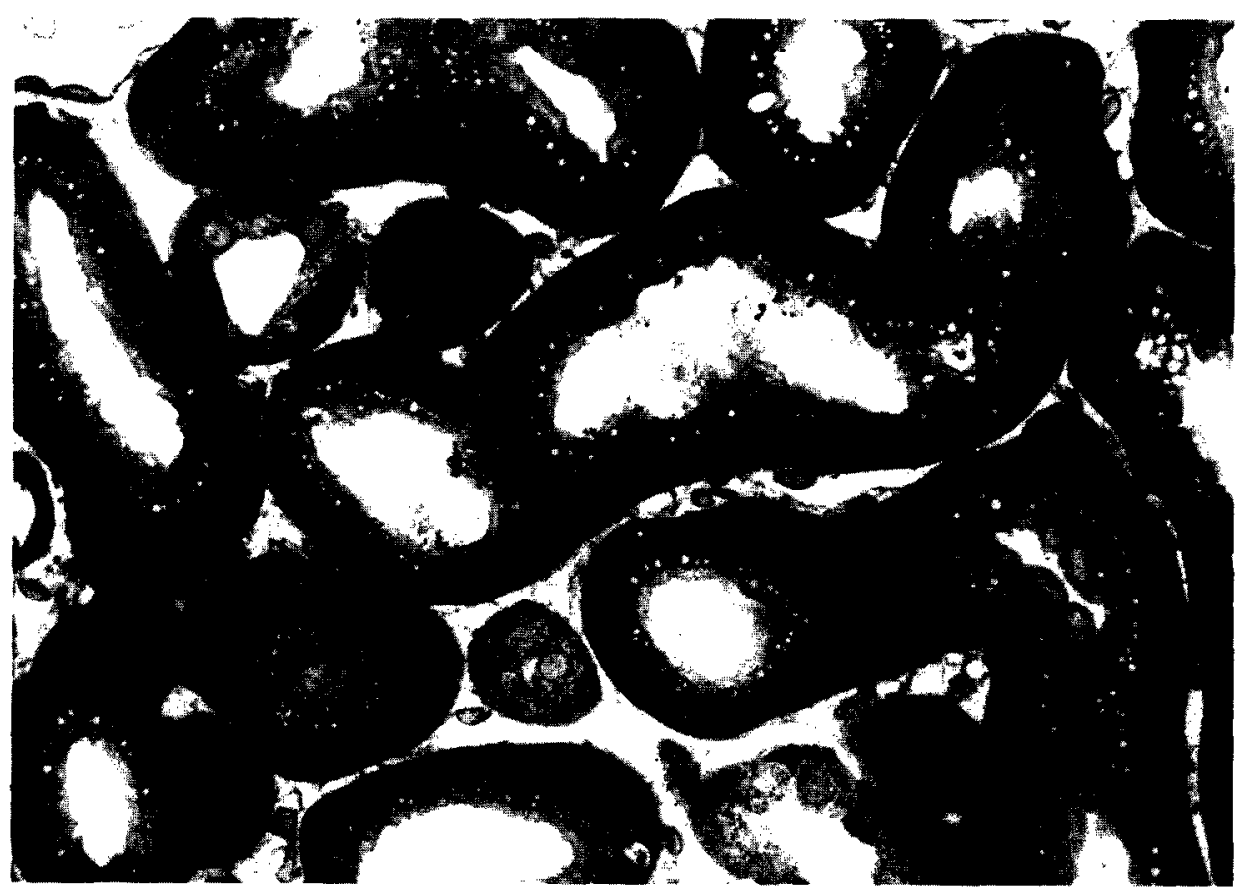

FIG. 1. Representative semithin section of outer cortex stained with toluidine blue $(\times 680)$ from rat treated with $100 \mathrm{mg} / \mathrm{kg}$ gentamicin for 4 days. 
the last of four $100 \mathrm{mg} / \mathrm{kg}$ doses of gentamicin, gross tubule structure remained intact; however, large numbers of myeloid bodies and focal loss of brush border in $S_{1}$ and $S_{2}$ proximal tubule segments as previously reported for similar treatment protocols were present (Fig. 1) (Simmons et al., 1980; Soberon et al., 1979). After 10 doses of gentamicin, there was widespread necrosis in outer cortex with complete denudation of tubular basement membrane in some areas and replacement of the normal tubular epithelium with a lining of flat poorly differentiated cells in other areas (Fig. 2). Tubule structure was better preserved in inner cortex and outer medulla areas where $S_{3}$ proximal tubule segments are prominent but large casts filled in lumens of these tubules. An interstitial nephritis was also present. By light microscopy, tubular structure was well preserved $3 \mathrm{hr}$ after $\mathrm{HgCl}_{2}$ but ultrastructural studies showed the presence, mainly within $S_{1}$ and $S_{2}$ segments, of increased numbers of small vesicles, dense bodies, and vacuoles (Fig. 3). At $12 \mathrm{hr}$ after $\mathrm{HgCl}_{2}$, extensive necrosis was present in $\mathrm{S}_{3}$ segments and to a lesser extent in $S_{2}$ segments with good preservation of tubular cell integrity in $S_{1}$ segments as previously reported by others (Fig. 4) (Gritzka and Trump, 1968; Barnes et al., 1980). These data indicate that the points chosen for study in these models spanned a range of injury from the developing phase prior to loss of renal tubular cell integrity ( $3 \mathrm{hr}$ for $\mathrm{HgCl}_{2}, 4$ or fewer doses for gentamicin) well into the period during which advanced cellular injury with nccrosis was widespread (12 hr for $\mathrm{HgCl}_{2}, 10$ doses for gentamicin) and severe sustained loss of renal excretory function had occurred.

\section{Functional Changes of Isolated Renal Cortical Mitochondria}

Basic mitochondrial respiratory parameters are summarized in Table III. Mild, but significant inhibitions of State 3 respiratory rates and 2,4-dinitrophenol (DNP)

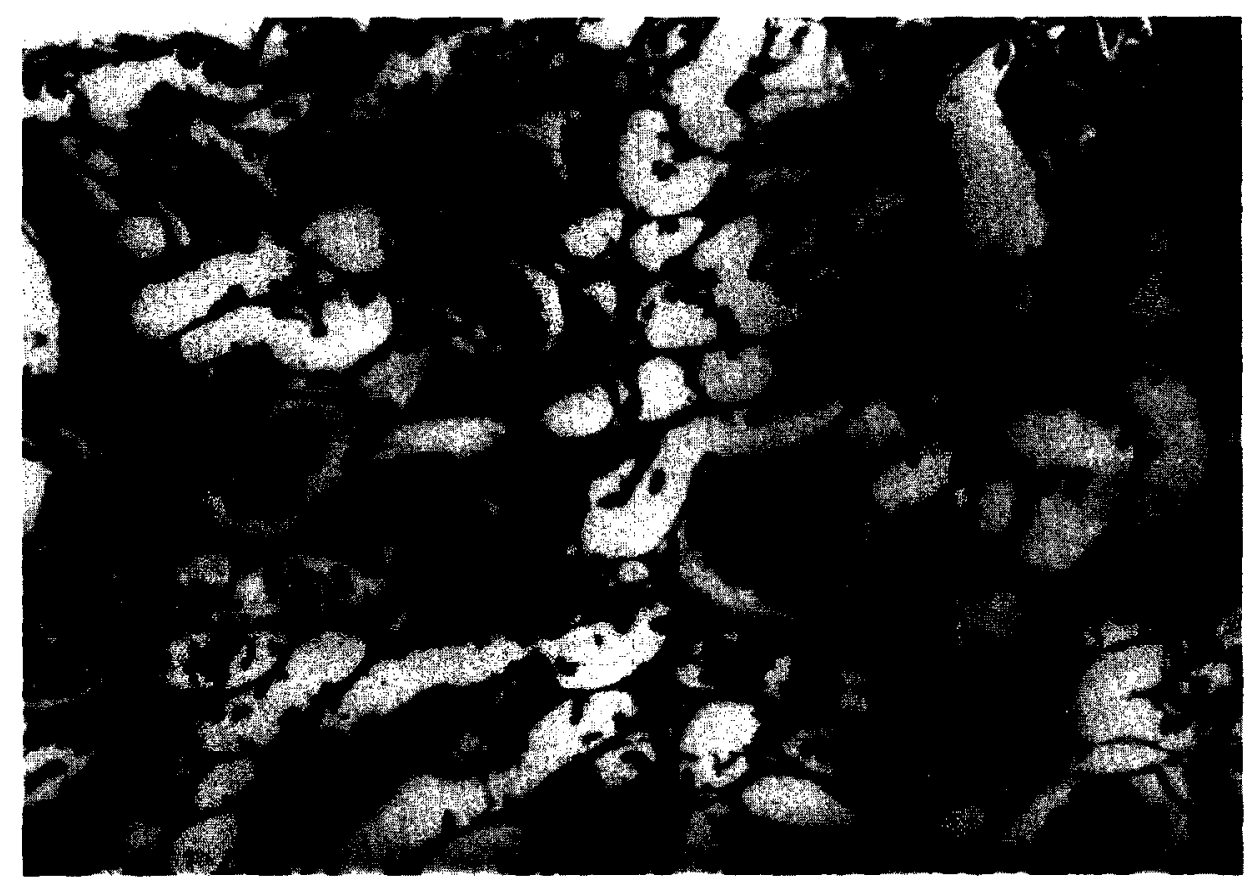

FIG. 2. Representative H\&E-stained section of outer cortex $(\times 275)$ from rat treated with $100 \mathrm{mg} /$ kg gentamicin for 10 days. 

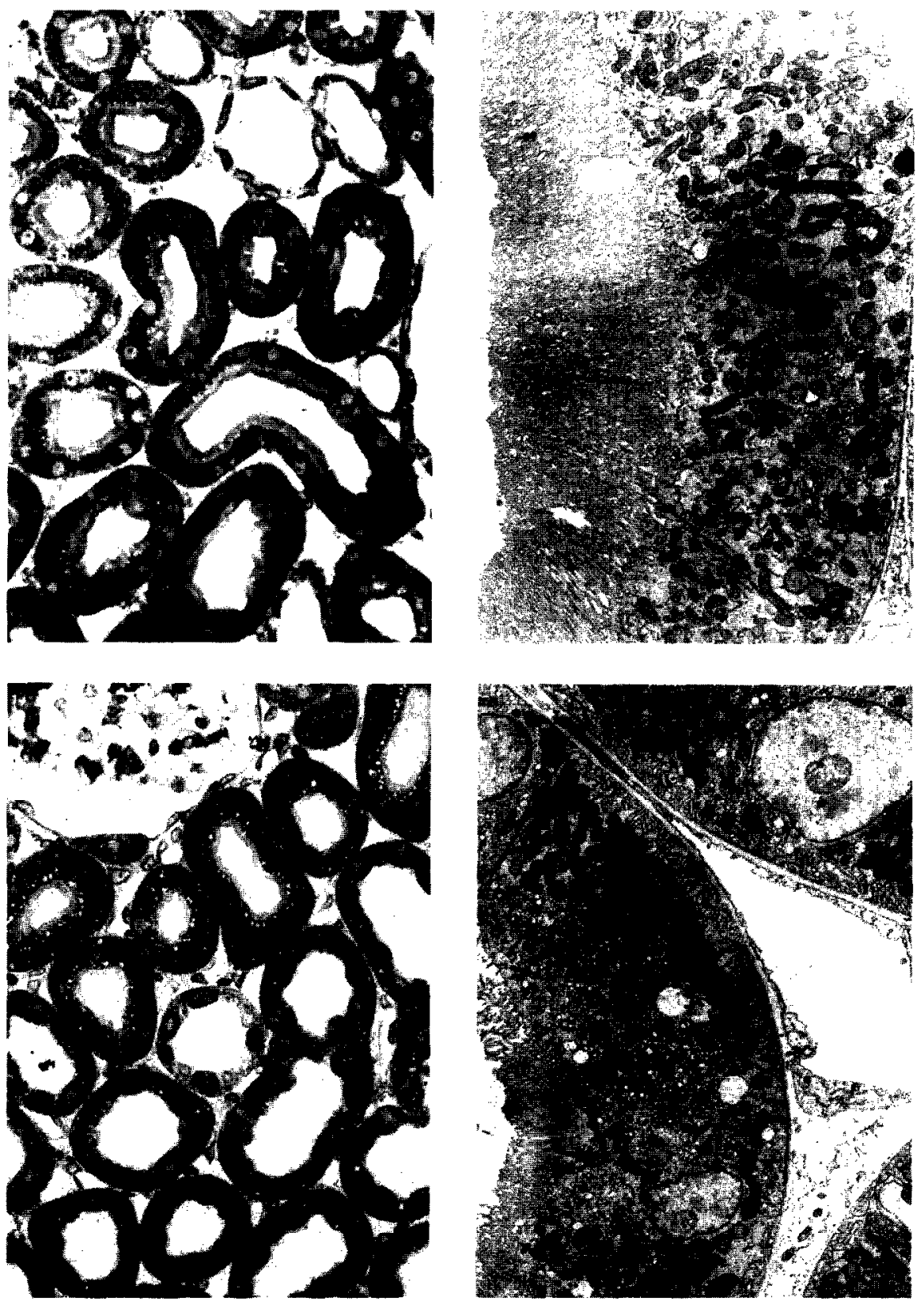

FIG. 3. Morphology of rat kidney $3 \mathrm{hr}$ after $5 \mathrm{mg} / \mathrm{kg} \mathrm{HgCl}_{2}$. Frames on the left are toluidine bluestained semithin sections of outer cortex (bottom) and outer medulla (top) $(\times 200)$. Frames on the right are electron micrographs of $S_{2}$ (bottom) and $S_{3}$ (top) proximal tubule segments $(\times 3600)$. 


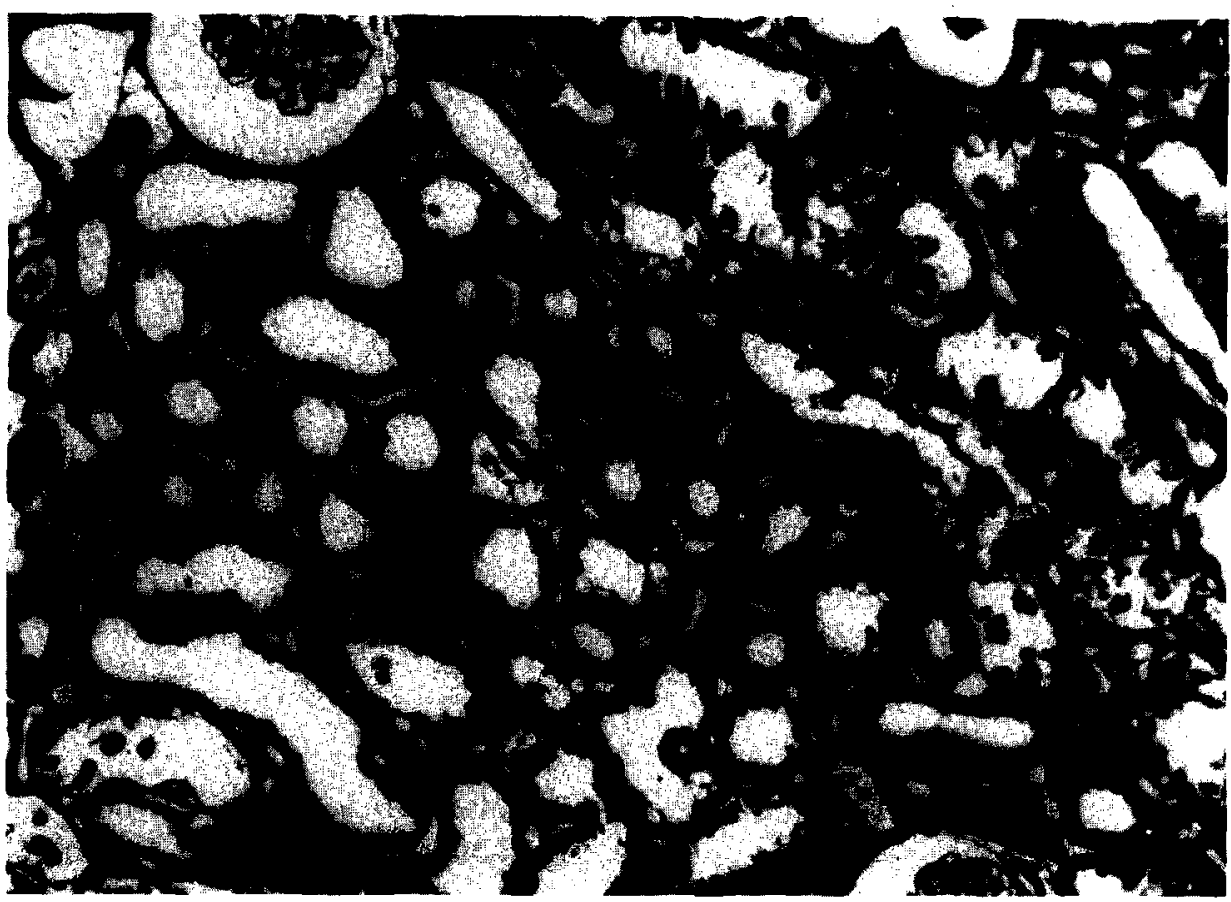

Fig. 4. Representative H\&E-stained section of outer cortex ( $\times 275) 12 \mathrm{hr}$ after treatment with $5 \mathrm{mg} /$ $\mathrm{kg} \mathrm{HgCl}$.

uncoupled rates were present at $3 \mathrm{hr}$ after $\mathrm{HgCl}_{2}$ and after 4 doses of gentamicin. For both $\mathrm{HgCl}_{2}$ (as previously reported in Weinberg et al., 1982b) and gentamicin (data in Table III) the inhibitory cffects appcared to be more marked with sodium pyruvate-sodium malate than with sodium succinate as substrate.

TABLE III

Respiratory Function of Isolated Mitochondria ${ }^{a}$

\begin{tabular}{lrrcc}
\hline & & \multicolumn{3}{c}{$\begin{array}{c}\text { Respiratory rate } \\
\text { (natom eq O/mg protein/min) }\end{array}$} \\
\cline { 3 - 5 } & $N$ & \multicolumn{1}{c}{ State 4} & State 3 & DNP uncoupled \\
\hline Control $^{b}$ & 10 & $107 \pm 2$ & $380 \pm 6$ & $400 \pm 8$ \\
$3-\mathrm{hr} \mathrm{Hg}^{2+}$ & 12 & $103 \pm 3$ & $321 \pm 8^{* * *}$ & $362 \pm 9^{* *}$ \\
12-hr Hg $^{2+}$ & 8 & $94 \pm 9$ & $178 \pm 35^{* * *}$ & $224 \pm 41^{* * *}$ \\
Control $^{b}$ & 11 & $107 \pm 2$ & $390 \pm 8$ & $409 \pm 5$ \\
4-dose gentamicin & 14 & $99 \pm 3$ & $350 \pm 10^{* *}$ & $366 \pm 9^{* *}$ \\
Control c & 11 & $44 \pm 2$ & $175 \pm 6$ & $107 \pm 3$ \\
4-dose gentamicin & 14 & $39 \pm 2$ & $135 \pm 6^{* * *}$ & $88 \pm 4^{* *}$ \\
Control & 4 & $103 \pm 4$ & $407 \pm 12$ & $428 \pm 14$ \\
10-dose gentamicin & 5 & $84 \pm 7$ & $160 \pm 20^{* * *}$ & $189 \pm 24^{* * *}$ \\
\hline
\end{tabular}

- Data for each experimental group are given with data from the concurrent control group. $N$-number of experiments. Relative to corresponding control ${ }^{* *} P<0.01,{ }^{* * *} P<0.001$.

${ }^{b}$ Respiratory substrate for this control group and its corresponding experimental groups was 10 $\mathrm{m} M$ sodium succinate.

- Respiratory substrate for this control group and its corresponding experimental group was $5 \mathrm{~m} M$ sodium pyruvate- $5 \mathrm{~m} M$ sodium malate. 
TABLE IV

Renal Cortex Water and Protein Content ${ }^{a}$

\begin{tabular}{lccc}
\hline & & \multicolumn{2}{c}{ Mean ratios \pm SE } \\
\cline { 3 - 4 } & $N$ & \multicolumn{1}{c}{ Dry wt/wet wt } & Tissue protein/dry wt \\
\hline Control & 9 & $0.222 \pm 0.001$ & $0.72 \pm 0.01$ \\
3-hr Hg & 5 & $0.214 \pm 0.002$ & $0.72 \pm 0.01$ \\
12-hr Hg & 6 & $0.168 \pm 0.004^{* * *}$ & $0.73 \pm 0.01$ \\
Control & 8 & $0.242 \pm 0.001$ & $0.72 \pm 0.01$ \\
4-dose gentamicin & 8 & $0.230 \pm 0.005$ & $0.73 \pm 0.01$ \\
10-dose gentamicin & 3 & $0.143 \pm 0.003^{* * *}$ & $0.72 \pm 0.04$ \\
\hline
\end{tabular}

a Dry and wet weights of renal cortex were determined as under Methods on renal cortex obtained from the right kidney. Renal cortex from the left kidney was carefully weighed prior to homogenization as described under Methods, then protein content was determined on a sample of homogenate. The dry weight of the left renal cortex sample was estimated by multiplying its wet weight by the dry/wet weight ratio obtained from the corresponding right kidney. $N=$ number of experiments.

*** $P<0.001$ relative to control.

In the setting of advanced tissue injury, $12 \mathrm{hr}$ after $\mathrm{HgCl}_{2}$ and after 10 doses of gentamicin, severe dysfunction of isolated mitochondria characterized by marked inhibitions of State 3- and DNP-uncoupled rates was present.

\section{Effects on Tissue Water and Protein Content}

These parameters, as summarized in Table IV, were determined in an untreated control group, at 3 and $12 \mathrm{hr}$ after $\mathrm{HgCl}_{2}$ and after 4 and 10 doses of gentamicin. Of these groups, tissue water was significantly increased (decreased dry to wet weight ratio) in the 12-hr $\mathrm{HgCl}_{2}$ and 10-dose gentamicin groups, concomitant with the presence of advanced injury. The tissue protein/dry weight ratios, however, were not altered under any of the conditions tested, indicating that relative changes in tissue electrolyte levels factored for either value should be equivalent.

\section{Renal Cortex Cation Levels}

In studies done on homogenates of renal cortex, no changes had occurred in any cation at $3 \mathrm{hr}$ after $\mathrm{HgCl}_{2}$. At $12 \mathrm{hr}$ after $\mathrm{HgCl}_{2}$, tissue $\mathrm{Na}^{+}$and $\mathrm{Ca}^{2+}$ were markedly elevated and $\mathbf{M g}^{2+}$ was slightly increased. $\mathrm{K}^{+}$was not significantly affected, but was more variable than in the control or 3-hr groups.

In studies done on homogenates of renal cortex, tissue $\mathrm{Mg}^{2+}$ was substantially decreased while $\mathrm{K}^{+}$was slightly but significantly decreased after 4 doses of gentamicin. Small but significant decreases in $\mathrm{Na}^{+}$and $\mathrm{Ca}^{2+}$ were also detected in this group of experiments.

After 10 doses of gentamicin, marked increases in tissue $\mathrm{Na}^{+}$and $\mathrm{Ca}^{2+}$ were seen while $\mathrm{Mg}^{2+}$ was moderately increased. These changes are similar to those seen $12 \mathrm{hr}$ after $\mathrm{HgCl}_{2}$. Tissue $\mathrm{K}^{+}$was significantly increased in the 10-dose gentamicin group (Table V).

In general, the results of the studies done on dried renal cortex digested with concentrated $\mathrm{HNO}_{3}$ were similar to those obtained on the tissue homogenates. No alterations in cation content were present $3 \mathrm{hr}$ after $\mathrm{HgCl}_{2}$. Twelve hours after $\mathrm{HgCl}_{2}$, marked increases in $\mathrm{Na}^{+}$and $\mathrm{Ca}^{2+}$ were present. After 4 doses of genta- 
TABLE V

Cation Content of Whole Renal Cortex

\begin{tabular}{|c|c|c|c|c|c|}
\hline & $\mathbf{N}$ & $\mathbf{K}^{+}$ & $\mathrm{Na}^{+}$ & $\mathrm{Ca}^{2+}$ & $\mathrm{Mg}^{2+}$ \\
\hline \multicolumn{6}{|c|}{ A. Measurements made on homogenates of renal cortex $(\mathrm{nmol} / \mathrm{mg}$ protein $\pm \mathrm{SE})$} \\
\hline Control & 17 & $439 \pm 5$ & $313 \pm 5$ & $11.9 \pm 0.4$ & $44.8 \pm 0.8$ \\
\hline 3-hr $\mathrm{Hg}^{2+}$ & 18 & $425 \pm 5$ & $322 \pm 5$ & $12.2 \pm 0.4$ & $44.8 \pm 1.0$ \\
\hline 12-hr $\mathrm{Hg}^{2+}$ & 8 & $422 \pm 21$ & $609+35^{* * *}$ & $65.6 \pm 12.0^{* * *}$ & $47.8 \pm 1.2^{*}$ \\
\hline Control & 11 & $424 \pm 11$ & $359 \pm 13$ & $8.9 \pm 0.2$ & $50.8 \pm 1.3$ \\
\hline 4-dose gentamicin & 14 & $393 \pm 8^{*}$ & $304 \pm 10^{* *}$ & $8.1 \pm 0.3^{*}$ & $43.1 \pm 1.1^{* * *}$ \\
\hline Control & 4 & $394 \pm 14$ & $336 \pm 9$ & $9.7 \pm 0.4$ & $49.2 \pm 1.2$ \\
\hline 10-dose gentamicin & 5 & $529 \pm 24^{* *}$ & $669 \pm 23^{* * *}$ & $46.0 \pm 8.3^{*}$ & $58.2 \pm 2.5^{*}$ \\
\hline \multicolumn{6}{|c|}{ B. Measurements made on dried renal cortex dissolved in nitric acid $(\mathrm{nmol} / \mathrm{mg}$ dry weight $\pm \mathrm{SE}$ ) } \\
\hline Control & 6 & $303 \pm 5$ & $207 \pm 4$ & $9.3 \pm 0.6$ & $37.5 \pm 0.6$ \\
\hline 3-hr $\mathrm{Hg}^{2+}$ & 5 & $308 \pm 4$ & $227 \pm 10$ & $10.5 \pm 0.4$ & $38.3 \pm 0.4$ \\
\hline Control & 8 & $307 \pm 3$ & $235 \pm 3$ & $7.2 \pm 0.2$ & $34.9 \pm 0.5$ \\
\hline 12-hr $\mathrm{Hg}^{2+}$ & 3 & $297 \pm 1$ & $330 \pm 20^{* * *}$ & $24.8 \pm 0.5^{* * *}$ & $37.9 \pm 0.4^{*}$ \\
\hline Control & 16 & $302 \pm 2$ & $225 \pm 2$ & $7.4 \pm 0.1$ & $35.2 \pm 0.2$ \\
\hline 4-dose gentamicin & 8 & $285 \pm 4^{* * *}$ & $232 \pm 13$ & $8.5 \pm 1.0$ & $30.7 \pm 0.6^{* * *}$ \\
\hline
\end{tabular}

Note. $N=$ number of experiments. Relative to corresponding control group: ${ }^{*} P<0.05,{ }^{* *} P<$ $0.01,{ }^{* * *} P<0.001$.

micin, tissue $\mathrm{Mg}^{2+}$ was substantially decreased while tissue $\mathrm{K}^{+}$was slightly decreased. Unlike the studies done on tissue homogenates, there were no differences in $\mathrm{Na}^{+}$and $\mathrm{Ca}^{2+}$ between the control and 4-dose gentamicin groups in the experiments done for the determination of electrolytes on dried tissue samples digested in $\mathrm{HNO}_{3}$.

\section{Mitochondrial Cation Levels}

Three hours after $\mathrm{HgCl}_{2}$, isolated mitochondria showed small but significant decreases in $\mathrm{K}^{+}$and $\mathrm{Mg}^{2+}$ content relative to simultaneously studied controls. However, it should be noted that the actual levels of $\mathrm{K}^{+}$and $\mathrm{Mg}^{2+}$ in the mitochondria from the $\mathrm{HgCl}_{2}$-treated rats were still within the range of normal values recorded for control mitochondrial preparations studied at other times for different experiments. Twelve hours after $\mathrm{HgCl}_{2}$, mitochondria had markedly increased content of $\mathrm{Ca}^{2}$, moderately increased $\mathrm{Na}^{+}$, and markedly decreased $\mathrm{K}^{+}$.

Mitochondria isolated after 4 doses of gentamicin showed significantly decreased levels of $\mathrm{K}^{+}$but no significant changes in other cations. When isolated at the time of advanced injury, after 10 doses, the mitochondria showed marked increases in $\mathrm{Ca}^{2+}$ and $\mathrm{Na}^{+}$, a small increase in $\mathrm{Mg}^{2+}$, and markedly decreased $\mathrm{K}^{+}$(Table VI).

\section{Influence of Mitochondrial Isolation Conditions on Their $\mathrm{Ca}^{2+}$ Content}

Due to the obligate mixing of the intra- and extracellular contents which occurs during tissue homogenization, mitochondria are transiently exposed to higher concentrations of $\mathrm{Ca}^{2+}$ during their isolation than they are exposed to in situ and $\mathrm{Ca}^{2+}$ uptake may occur with resulting changes in both mitochondrial $\mathrm{Ca}^{2+}$ content and subsequent function (Peng et al., 1977; Van Rossum et al., 1976). For this reason, a calcium chelator, EGTA, is routinely included in the tissue-homo- 
TABLE VI

Cation Content of Isolated Renal Cortical Mitochondria ${ }^{a}$

\begin{tabular}{lrcccc}
\hline & & \multicolumn{5}{c}{ Content (nmol/mg protein $\pm \mathrm{SE})$} \\
\cline { 3 - 6 } & $N$ & $\mathrm{~K}^{+}$ & $\mathrm{Na}^{+}$ & $\mathrm{Ca}^{2+}$ & $\mathrm{Mg}^{2+}$ \\
\hline Control & 17 & $117 \pm 2$ & $12.2 \pm 1.0$ & $11.0 \pm 0.4$ & $33.0 \pm 0.5$ \\
3-hr Hg & 18 & $109 \pm 2^{* *}$ & $11.7 \pm 0.6$ & $11.8 \pm 0.5$ & $31.1 \pm 0.7^{*}$ \\
12-hr Hg & 8 & $62 \pm 8^{* * *}$ & $18.6 \pm 1.4^{* * *}$ & $41.9 \pm 10.2^{* * *}$ & $33.6 \pm 1.5$ \\
Control & 11 & $107 \pm 2$ & $12.0 \pm 0.9$ & $9.8 \pm 0.5$ & $32.1 \pm 0.8$ \\
4-dose gentamicin & 14 & $96 \pm 3^{* *}$ & $10.2 \pm 0.5$ & $11.3 \pm 0.5$ & $30.8 \pm 0.5$ \\
Control & 4 & $101 \pm 3$ & $12.2 \pm 1.5$ & $10.5 \pm 0.6$ & $31.4 \pm 0.4$ \\
10-dose gentamicin & 5 & $67 \pm 7^{* *}$ & $36.8 \pm 4.7^{* *}$ & $64.4 \pm 10.3^{* *}$ & $37.2 \pm 1.2^{* *}$ \\
\hline
\end{tabular}

${ }^{a}$ Relative to corresponding control group ${ }^{*} P<0.05,{ }^{* *} P<0.01,{ }^{* *} P<0.001 . N=$ number of experiments.

genizing medium. It is possible, however, that EGTA may act to remove a portion of mitochondrial $\mathrm{Ca}^{2+}$ which was present in situ and may, thereby, serve to obscure a small early difference in mitochondrial $\mathrm{Ca}^{2+}$ levels between control and nephrotoxin groups. To assess this issue, renal cortical mitochondria were isolated from control kidney cortex and $3 \mathrm{hr}$ after $\mathrm{HgCl}_{2}$ in either the standard EGTA-containing homogenizing medium or a medium containing $0.275 \mathrm{M}$ su-

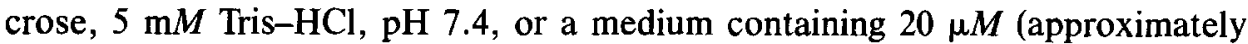
$1.3 \mathrm{nmole} / \mathrm{mg}$ protein) ruthenium red, a potent specific inhibitor of mitochondrial $\mathrm{Ca}^{2+}$ uptake which is not a $\mathrm{Ca}^{2+}$ chelator (Reed and Bygrave, 1974). As shown in Fig. 5, the mitochondria isolated in $0.275 M$ sucrose, $5 \mathrm{mM}$ Tris- $\mathrm{HCl}$ had the highest $\mathrm{Ca}^{2+}$ levels. The lowest $\mathrm{Ca}^{2+}$ levels were in the mitochondria isolated with EGTA, while those isolated with ruthenium red were intermediate. Of note,

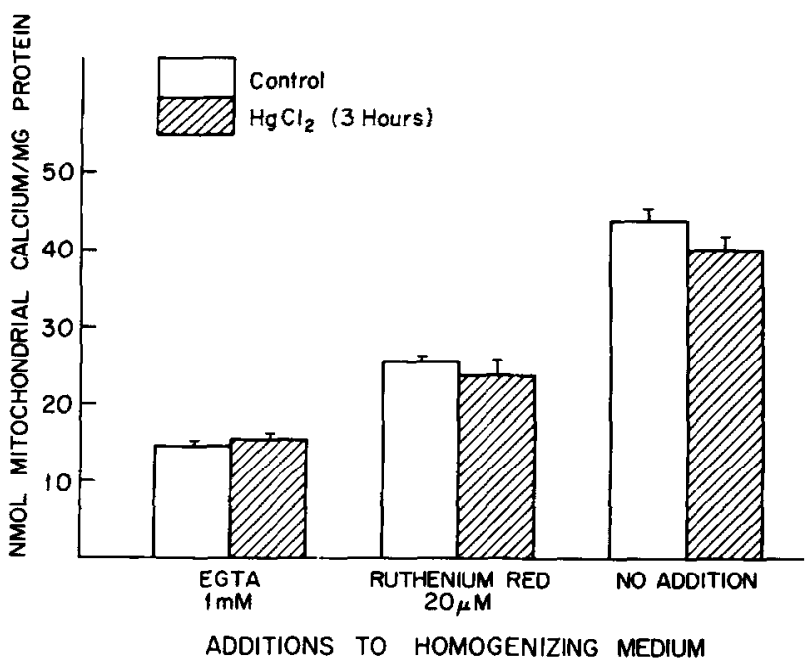

FIG. 5. Effect of the composition of the medium used to homogenize the renal cortex on the $\mathrm{Ca}^{2+}$ content of the mitochondrial fraction as finally isolated. The homogenizing medium contained 0.275 $M$ sucrose, $5 \mathrm{~m} M$ Tris- $\mathrm{HCl}, \mathrm{pH} \mathrm{7.4,} \mathrm{and} \mathrm{the} \mathrm{indicated} \mathrm{additions.} \mathrm{The} \mathrm{HgCl}_{2}$ group received $5 \mathrm{mg} / \mathrm{kg}$ $3 \mathrm{hr}$ prior to sacrifice. All control groups, $N=6, \mathrm{HgCl}_{2}, 1 \mathrm{~m} M$ EGTA, $N=3, \mathrm{HgCl}_{2}$, ruthenium red, and no addition groups, $N=5$. 
TABLE VII

Sequential Changes in Renal Cortex and Muscle $\mathrm{K}^{+}$and $\mathrm{Mg}^{2+}$ Content during Early Gentamicin Nephrotoxicity

\begin{tabular}{lcccc}
\hline & \multicolumn{4}{c}{ Number of gentamicin doses } \\
\cline { 2 - 5 } & $\begin{array}{c}\text { Control } \\
(N=16)\end{array}$ & $\begin{array}{c}1 \\
(N=8)\end{array}$ & $\begin{array}{c}2 \\
(N=8)\end{array}$ & $(N=8)$ \\
\hline & & (nmol/mg dry wt $\pm \mathrm{SE})$ & \\
$\mathrm{K}^{+}$ & $302 \pm 2$ & $308 \pm 3$ & $304 \pm 3$ & $285 \pm 4^{* * *}$ \\
$\quad \begin{array}{l}\text { Renal cortex } \\
\text { Muscle }\end{array}$ & $445 \pm 4$ & $449 \pm 2$ & $444 \pm 1$ & $431 \pm 6^{*}$ \\
$\begin{array}{l}\text { Mg } \\
\text { Renal cortex }\end{array}$ & $35.2 \pm 0.2$ & $34.2 \pm 0.7$ & $33.7 \pm 0.5^{* *}$ & $30.7 \pm 0.6^{* * *}$ \\
$\quad$ Muscle & $42.6 \pm 0.4$ & $40.7 \pm 0.6$ & $41.2 \pm 1.0$ & $43.3 \pm 0.6$ \\
\hline
\end{tabular}

a $N=$ number of rats studied.

Relative to control, ${ }^{*} P<0.05,{ }^{* *} P<0.01,{ }^{* * *} P<0.001$.

however, $\mathrm{Ca}^{2+}$ contents of mitochondria isolated from rats treated $3 \mathrm{hr}$ previously with $\mathrm{HgCl}_{2}$ did not differ from those of controls with any of the isolation methods.

These studies suggest that EGTA in addition to preventing $\mathrm{Ca}^{2+}$ uptake (as ruthenium red alone does) also removes a component of bound $\mathrm{Ca}^{2+}$ but that this effect is not serving to obscure any difference between $\mathrm{Hg}^{2+}$-treated and control mitochondria.

\section{Sequential Changes in $\mathrm{K}^{+}$and $\mathrm{Mg}^{2+}$ during Developing}

\section{Gentamicin Nephrotoxicity}

To further assess the renal cortex $\mathrm{Mg}^{2+}$ and $\mathrm{K}^{+}$depletion seen after 4 doses of gentamicin, additional studies were done using dried samples of renal cortex as well as samples of muscle obtained after 1, 2, and 4 doses of gentamicin. As summarized in Table VII, $\mathrm{Mg}^{2+}$ depletion was detected in kidney after as few as two doses of gentamicin and was specific for kidney since at no point were changes in muscle levels seen. In contrast, tissue $\mathrm{K}^{+}$depletion appeared in kidney only after the 4th dose and, at that time, was accompanied by a similar decrease in muscle $\mathrm{K}^{+}$. Since it has been suggested that muscle $\mathrm{Mg}^{2+}$ may be less sensitive as an indicator of total body $\mathrm{Mg}^{2+}$ depletion than serum $\mathrm{Mg}^{2+}$ (Dunn and Wasler, 1966), serum $\mathrm{Mg}^{2+}$ levels were also determined in the same groups (Table VIII). They were not decreased at any point.

TABLE VIII

Serum $\mathrm{Mg}^{2+}$ Levels during Developing Gentamicin Nephrotoxicity ${ }^{a}$

\begin{tabular}{crccc}
\hline & \multicolumn{5}{c}{ Number of doses of gentamicin } \\
\cline { 2 - 5 } & Control & 1 & 2 & 4 \\
\hline $\begin{array}{c}\text { Serum } \mathrm{Mg}^{2+} \\
(\mathrm{meq} / \mathrm{l})\end{array}$ & 1.66 & 1.72 & 1.68 & $1.92^{* * *}$ \\
\hline
\end{tabular}

*** $P<0.001$, relative to control. 


\section{DISCUSSION}

Previous studies have provided valuable but somewhat fragmentary information on cellular electrolyte shifts during renal injury. Renal slices subjected to either anoxia or hypothermia show marked cellular electrolyte shifts acutely predominated by loss of intracellular $\mathrm{K}^{+}$and uptake of $\mathrm{Na}^{+}$and water (Mudge, 1951; MacKnight, 1968; Whittembury and Proverbio, 1970; Trump et al., 1974). Divalent cation metabolism has not been extensively studied but available data suggest there also occurs, under these conditions, an increase in intracellular $\mathrm{Ca}^{2+}$ but little change in $\mathrm{Mg}^{2}+$ (MacKnight, 1968). Of note, these acute changes occur in the absence of any alteration in the extracellular space as measured with inulin so the alterations are reflected in whole-tissue values as well as those corrected for extracellular volume (Whittembury and Proverbio, 1970). A recent electron microprobe study has demonstrated very similar alterations in cellular $\mathrm{Na}^{+}$ and $\mathrm{K}^{+}$metabolism during in vivo ischemia (Mason et al., 1981). If slices are reoxygenated (or rewarmed and provided with substrate) or the whole kidney is reperfused in situ (Mudge, 1951; MacKnight, 1968; Whittembury and Proverbio, 1970; Mason et al., 1981) recovery of $\mathrm{Na}^{+}$and $\mathrm{K}^{+}$levels towards normal occurs but little is known of how cells destined to go on to necrosis differ from those destined to recover. Hours after the ischemic episode and reflow, when necrosis has occurred, kidney tissue levels of $\mathrm{Na}^{+}$and $\mathrm{Ca}^{2+}$ are high, $\mathrm{K}^{+}$is depressed, and $\mathrm{Mg}^{2+}$ is variably altered (Keeler, 1968), a pattern similar to that seen in cardiac (Whalen et al., 1974) and hepatic injury (Gallagher et al., 1956; Thiers et al., 1960).

Studies of nephrotoxic renal injury are more limited. Carafoli et al. (1971) studied changes in electrolyte content of mitochondria isolated during uranyl nitrate toxicity. They showed progressive increases in $\mathrm{Ca}^{2+}$ and $\mathrm{Na}^{+}$and loss of $\mathrm{K}^{+}$but close correlations between the time course of these events, kidney function, anatomical changes, and mitochondrial function were not reported. Cronin et al. (1982), in a dog model of gentamicin nephrotoxicity, found an early decrease in tissue $\mathrm{K}^{+}$and $\mathrm{Mg}^{2+}$ after gentamicin treatment which was not, however, predictive of degree of injury. When creatinine was substantially elevated, tissue $\mathrm{Na}^{+}$and $\mathrm{Ca}^{2+}$ were increased. Renal cortical Na-K-ATPase activity was also decreased at this late interval (Cronin et al., 1982).

The data on tissue and mitochondrial cation levels obtained in the present study must be interpreted in the context of the degree of tissue injury present. In the control groups and at the early stages of injury studied, i.e., $3 \mathrm{hr}$ after $\mathrm{HgCl}_{2}$ and 4 or fewer doses of gentamicin, when morphologic integrity is still preserved and tissue dry/wet weight ratios are not altered, the measurements of tissue $\mathrm{K}^{+}$and $\mathrm{Mg}^{2+}$ largely reflect intracellular levels. Though not measured in the present study, the extracellular space of the kidneys, as isolated, is likely intermediate between the value of $26 \%$ of wet weight measured with inulin in incubated slices (Whittembury and Proverbio, 1970) and 39\% of tissue volume measured by planimetry in perfusion-fixed tissues (Mason et al., 1981). Based on the serum and tissue electrolyte levels measured in the present study it can be calculated using these estimates of the extracellular space that $98-98.7 \%$ of the $\mathrm{K}^{+}$and $95.7-$ 97.1\% of the $\mathrm{Mg}^{2+}$ are intracellular. On the other hand, less than $35 \%$ of the $\mathrm{Na}^{+}$ and $65 \%$ of the $\mathrm{Ca}^{2+}$ are intracellular. Thus, changes in tissue $\mathrm{K}^{+}$and $\mathrm{Mg}^{2+}$ are good indicators of changes in intracellular levels under these conditions while 
changes in $\mathrm{Na}^{+}$and $\mathrm{Ca}^{2+}$ are much more subject to pertubations in extracellular volume and are, therefore, less precise and reproducible indicators of cellular levels. This is illustrated by the results of the 4-dose gentamicin experiments. In the first set of studies, done to obtain tissue homogenate (and mitochondrial) cation levels, the gentamicin-treated group had decreases in homogenate levels of all four cations measured. When the experiment was repeated a subsequent time on separate groups of rats to measure cation levels on dried tissue samples, only $\mathrm{K}^{+}$and $\mathrm{Mg}^{2+}$ levels were low in the treated rats while $\mathrm{Na}^{+}$and $\mathrm{Ca}^{2+}$ no longer differed from controls.

When necrosis has occurred, no tissue electrolyte value can be interpreted as an unequivocal indicator of intracellular levels because of the imprecise and variable separation of the intra- and extracellular spaces at this time. However, the pattern of electrolyte changes and their severity may provide clues to the factors involved in promoting injury at that point and may be useful in grading the degree of injury present.

Mitochondrial electrolyte levels are of value in assessing degree of mitochondrial injury and in interpreting the changes occurring in the whole-tissue electrolyte values. The normal mitochondrial membrane has a low passive permeability to cations (Humes and Weinberg, 1983; Brierley and Jung, 1980) and, in fact, is dependent on this property for its normal integrated function (Humes and Weinberg, 1983). The fact that mitochondria after being washed during their isolation with sucrose solutions free of added cations retain large amounts of $\mathrm{K}^{+}$and $\mathrm{Mg}^{2+}$ reflects this relative impermeability of the inner mitochondrial membrane. Any factor altering the normal integrity of the membrane may serve to decrease the $\mathrm{K}^{+}$and $\mathrm{Mg}^{2+}$ content of the mitochondria as finally isolated. The stage at which loss occurred i.e., in situ or during isolation, cannot be specified. The presence of a high mitochondrial level of $\mathrm{Na}^{+}$and $\mathrm{Ca}^{2+}$ after the standard mitochondrial isolation procedures, on the other hand, suggests that those changes occurred in situ since the isolation procedures done in cation-free solution containing a $\mathrm{Ca}^{2+}$ chelator should serve only to lower, not to raise mitochondrial $\mathrm{Na}^{+}$and $\mathrm{Ca}^{2+}$ levels. The presence of mitochondrial $\mathrm{Ca}^{2+}$ overload, concomitant with increased tissue $\mathrm{Ca}^{2+}$, therefore, supports the notion that the increase in tissue $\mathrm{Ca}^{2+}$ was not limited to the extracellular space in situ, but was available to interact with mitochondria intracellularly.

Taking these considerations into account, the data reported in the present paper provide substantial insights into the timing and nature of the changes in cellular cation homeostasis occurring during nephrotoxic renal injury. In the model of $\mathrm{HgCl}_{2}$ nephrotoxicity utilized, previous detailed studies (Weinberg et al., 1982b) have established that functional alterations of isolated mitochondria became detectable 1-3 hr after treatment with the toxin, the time when intracellular $\mathrm{Hg}^{2+}$ levels are reaching their peak (Weinberg et al., 1982b; Kirschbaum et al., 1980). The present study demonstrates that (1) these changes in mitochondrial functional integrity are not secondary to cellular mitochondrial $\mathrm{Ca}^{2+}$ overload since none has occurred, (2) they are not secondary to other changes in tissue cation homeostasis since none have occurred, (3) neither these mitochondrial effects nor effects of $\mathrm{Hg}^{2+}$ at other cell sites have substantially disrupted overall cellular cation homeostasis during this interval, (4) the selective decreases in mitochondrial $\mathrm{K}^{\text {' }}$ and $\mathrm{Mg}^{2+}$ are compatible with the functional data demonstrating impaired functional integrity of the inner mitochondrial membrane, and (5) when tissue 
necrosis is present, cellular and mitochondrial $\mathrm{Ca}^{2+}$ overload occur as well documented in other states of advanced injury (Keeler, 1968; Whalen et al., 1975; Thiers et al., 1960; Gallagher et al., 1956; Mittnacht and Farber, 1981) and are accompanied by severe changes in mitochondrial function and electrolyte content.

The changes in cation homeostasis occurring during gentamicin toxicity differ from those seen in $\mathrm{HgCl}_{2}$ toxicity in several ways. (1) A prominent loss of tissue $\mathrm{Mg}^{2+}$ is seen early during the course of injury and, based on the absence of any concomitant effects on serum or muscle $\mathrm{Mg}^{2+}$, this appears to be specific for kidney. The $\mathrm{Mg}^{2+}$ depletion is a feature of early injury rather than late injury in which tissue $\mathrm{Mg}^{2+}$ is increased. The early substantial decrease in kidney $\mathbf{M g}^{2+}$ is similar to that reported in the dog model of gentamicin nephrotoxicity (Cronin et al., 1982) and may be related to the competitive interactions between gentamicin and $\mathbf{M g}^{2+}$ described in several renal membrane systems (Weinberg and Humes, 1980; Weinberg et al., 1980; Humes et al., 1982). (2) In contrast to data obtained with the dog (Cronin et al., 1982), the early depletion of kidney $\mathrm{K}^{+}$was delayed relative to that of $\mathrm{Mg}^{2+}$, was mild, and was accompanied by a similar loss of muscle $\mathrm{K}^{+}$. (3) As was the case for $\mathrm{HgCl}_{2}$ toxicity, no evidence for early cellular or mitochondrial $\mathrm{Ca}^{2+}$ overload was obtained. The early mitochondrial functional defects occurred prior to any changes in $\mathrm{Ca}^{2+}$. They wcre accompanicd by a decrease in mitochondrial $\mathrm{K}^{+}$but, interestingly, not in mitochondrial $\mathrm{Mg}^{2+}$ despite the marked concomitant change in tissue levels. (4) Late injury, like that seen with $\mathrm{HgCl}_{2}$, was characterized by tissue and mitochondrial $\mathrm{Ca}^{2+}$ overload.

In summary, cellular $\mathrm{Ca}^{2+}$ overload cannot be implicated as a progressive ongoing process in the early stages of either toxic lesion, nor can substantial changes in cellular $\mathrm{Na}^{+}$and $\mathrm{K}^{+}$homeostasis. The early mitochondrial functional changes are accompanied by mild losses of $\mathrm{K}^{+}$and, with $\mathrm{Hg}^{2+}, \mathrm{Mg}^{2+}$ from the mitochondria as isolated but are not accompanied by any changes in mitochondrial $\mathrm{Ca}^{2+}$ levels. $\mathrm{Ca}^{2+}$ overload is a common late feature of injury with both toxins. Selective kidney $\mathrm{Mg}^{2+}$ depletion is an early feature of gentamicin toxicity deserving further study as to its role in the pathogenesis of the renal tubular cell injury produced by gentamicin.

Recent data from J. L. Farber and his collaborators, although still controversial (Smith et al., 1981), have implicated cellular $\mathrm{Ca}^{2+}$ overload as a critical component in the pathogenesis of the transition from reversible to irreversible hepatic cell injury secondary to both ischemia (Farber et al., 1981; Mittnacht and Farber, 1981; Farber, 1982) and toxins, such as galactosamine (Farber, 1982). The results of the present study suggest that, if $\mathrm{Ca}^{2+}$ overload is the critical mediator of the transition from reversible to irreversible injury in the types of nephrotoxic renal tubular cell injury studied, it is a relatively abrupt and late process in the sequence of toxin-induced injurious subcellular events. If alterations of intracellular $\mathrm{Ca}^{2+}$ metabolism are involved in the early events of cell injury induced by these toxins, they are likely to involve changes of the intracellular regulation and sites of action of $\mathrm{Ca}^{2+}$ rather than a major net influx of the ion from the extracellular space.

\section{ACKNOWLEDGMENTS}

Portions of the data have been published previously in abstract form in Clin. Res. 29: 479A, 1981, and Kidney Int. 21: 218, 1982, and were presented at the 8th International Congress of Nephrology, Athens, 1981, and the 14th annual meeting of the American Society of Nephrology, Washington, 1981. These studies were supported in part by the Veterans Administration. Joel M. Weinberg is a Veterans 
Administration Research Associate. We thank Dr. T. Beals and Ms. Sue Stuth of the Ann Arbor V.A.M.C. electron microscope laboratory for expert preparation of the material processed for electron microscopy.

\section{REFERENCES}

AIthaL, H. N., and Toвack, F. G. (1978). Defective mitochondrial energy production during potassium depletion nephropathy. Lab. Invest. 39: 186-192.

Barnes, J. L., MCDowell, E. M., McNeil, J. S., Flamenaaum, W., and Trump, B. F. (1980). Studies on the pathophysiology of acute renal failure. IV. Protective effect of dithiothreitol following administration of mercuric chloride in the rat. Virchows Arch. [Cell Pathol.] 32: 201-232.

BRIERLEY, G. P., and JUNG, D. W. (1980). Inhibition of mitochondrial cation transport. Pharmacol. Ther. 8: 193-216.

Carafoli, E., Tiozzo, R., Pasquati-Ronchetti, I., and Laschi, R. (1971). A study of $\mathrm{Ca}^{2+}$ metabolism in kidney mitochondria during acute uranium intoxication. Lab. Invest. 25: 516-527.

Cronin, R., NiX, K., Ferguson, E., and Heinrich, W. (1982). Changes in renal cortex electrolyte content and Na-K-ATPase activity in early gentamicin nephrotoxicity. Amer. J. Physiol. 242, F477F483.

DunN, M. J., and WALSER, M. (1966). Magnesium depletion in normal man. Metabolism 15: 884-895.

FARBER, J. L. (1982). Membrane injury and calcium homeostasis in the pathogenesis of coagulative necrosis. Lab. Invest. 47: 114-123.

FARBer, J. L., ChIEN, K. R., and MitTANacht, S. (1981). The pathogenesis of irreversible cell injury in ischemia. Amer. J. Pathol. 102: 271-281.

Gallagher, C. H., Gupta, D. N., JudAh, J. D., and Rees, K. R. (1965). Biochemical changes in liver in acute thioacetamide intoxication. J. Pathol. Bacteriol. 72: 193-201.

GritZKa, T. L., and TRUMP, B. F. (1968). Renal tubular lesions caused by mercuric chloride. Amer. J. Pathol. 52: 1225-1227.

Humes, H. D. and Weinberg, J. M. (1983a). Alterations in renal tubular cell metabolism in acute renal failure. Mineral Electrolyte Metab., in press.

Humes, H. D., and WeInBerg, J. M. (1983b). Cellular energetics in acute renal failure. In "Acute Renal Failure" (B. M. Brenner and J. M. Lazarus, eds.), Saunders, Philadelphia, in press,

Humes, H. D., Weinbérg, J. M., and Knauss, T. C. (1982). Clinical and pathophysiological aspects of aminoglycoside nephrotoxicity. Amer. J. Kidney Dis. 2: 5-29.

JenNings, R. B., and ReImer, K. A. (1981). Lethal myocardial ischemic injury. Amer. J. Pathol. 102: 241-255.

KAMM, D. E., and STROPE, G. L. (1973), Glutamine and glutamate metabolism in renal cortex from potassium-depleted rats. Amer. J. Physiol. 224: 1241-1248.

KEELER, R. (1968). Composition and function of rat kidneys after transient normothermic ischemia. Canad. J. Physiol. Pharmacol. 46: 739-743.

Kirschbaum, B. B., SPRinkle, F. M., and OKen, D. E. (1980). Renal function and mercury levels in rats with mercuric chloride nephrotoxicity. Nephron 26: 28-34.

Lowry, O. H., Rosebrough, N. J., FARR, A. L., and RANDall, R. J. (1951). Protein measurement with the Folin phenol reagent. J. Biol. Chem. 193: 265-275.

MACKNIGHT, A. D. C. (1968). Water and electrolyte content of rat renal cortical slices incubated in potassium-free media and media containing ouabain. Biochim. Biophys. Acta 150: 263-270.

MASON, J., BECK, F., DORGE, A., RICK, R., and ThURAU, K. (1981). Intracellular electrolyte composition following renal ischemia. Kidney Int. 20: 61-70.

MITTNACHT, S., and FARBER, J. L. (1981). Reversal of ischemic mitochondrial dysfunction. J. Biol. Chem. 256: 3199-3206.

MUDGE, G. H. (1951). Studies on potassium accumulation by rabbit kidney slices: Effect of metabolic activity. Amer. J. Physiol. 165: 113-127.

Peng, C. F., Kane, J. J., Murphy, M. L., and Struab, K. D. (1977). Abnormal mitochondrial oxidative phosphorylation of ischemic myocardium reversed by $\mathrm{Ca}^{2+}$-chelating agents. J. Mol. Cell. Cardiol. 9: 897-908.

Reed, K. C., and Bygrave, F. L. (1974). The inhibition of mitochondrial calcium transport by lanthanides and ruthenium red. Biochem. J. 140: 143-155.

Simmons, C. F, , JR., BogUSKY, R. T., and HumEs, H. D. (1980). Inhibitory effects of gentamicin on renal cortical mitochondrial oxidative phosphorylation. J. Pharrmacol. Exp. Ther. 214: 709-715. 
Smith, M., Thor, H., and OrRenius, S. (1981). Toxic injury to isolated hepatocytes is not dependent on extracellular calcium. Science 213: 1257-1269.

Soberon, L., Bowman, R. L., Pastoriza-Munoz, E., and Kaloyanides, G. J. (1979). Comparative nephrotoxicities of gentamicin, netilmicin and tobramycin in the rat. J. Pharmacol. Exp. Ther. 210: 334-343.

Tew, W. P., Malis, C. D., and Walker, W. G. (1981). $\Lambda$ rapid extraction technique for atomic absorption determinations of kidney calcium. Anal. Biochem. 112: 346-350.

Thiers, R. E., Reynolds, E. S., and Vallee, B. L. (1960). The effect of carbon tetrachloride poisoning on subcellular metal distribution in rat liver. J. Biol. Chem. 235: 2130-2133.

Trump, B. F., Berezesky, I. K., Collan, Y., Kahng, M. W., and Mergner, W. J. (1976). Recent studies on the pathophysiology of ischemic cell injury. Beitr. Pathol. 158: 363-388.

Trijmp, B. F., Strum, J. M., and Bujg.r, R. F. (1974). Studies on the pathogenesis of ischemic cell injury. I. Relation between ion and water shifts and cell ultrastructure in rat kidney slices during swelling at $0-4^{\circ} \mathrm{C}$. Virchows Arch. [Cell Pathol.] 16: 1-34.

Van Rossum, G. D. V., Smith, K. P., and BeEton, P. (1976). Role of mitochondria in control of calcium content of liver slices. Nature (London) 260: 335-337.

Weinberg, J. M., Harding, P. G., and Humes, H. D. (1982a). Mitochondrial bioenergetics during the initiation of mercuric chloride-induced renal injury. I. Direct effects of in vitro mercuric chloride on renal cortical mitochondrial function. J. Biol. Chem. 257: 60-67.

Weinberg, J. M., Harding, P. G., and Humes, H. D. (1982b). Mitochondrial bioenergetics during the initiation of mercuric chloride-induced renal injury. II. Functional alterations of renal cortical mitochondria isolated after mercuric chloride treatment. J. Biol. Chem. 257: 68-74.

Weinberg, J. M., Harding, P. G., and Humes, H. D. (1980). Mechanisms of gentamicin-induced dysfunction of renal cortical mitochondria. II. Effects on mitochondrial monovalent cation transport. Arch. Biochem. Biohys. 205: 232-239.

WeinberG, J. M., and Humes, H. D. (1980). Mechanisms of gentamicin-induced dysfunction of renal cortical mitochondria. I. Effects on mitochondrial respiration. Arch. Biochem. Biophys, 205: $222-231$.

Whalen, D. A., Jr., Hamilton, D. G., Ganote, C. E., and Jennings, R. B. (1974). Effect of a transient period of ischemia on myocardial cells. I. Effects on cell volume regulation. Amer. $J$. Pathol. 74: 381-398.

Whittembury, G., and Proverbio, F. (1970). Two modes of $\mathrm{Na}^{+}$extrusion in cells from guinea pig kidney cortex slices. Pfluegers Arch. 316: 1-25.

Willard, H. H., Merrit, L. L., and Dean, J. A. (1974). "Instrumental Methods of Analysis," p. 382. Van Nostrand, New York. 